\title{
Energy Potential of Waste Derived from Some Food Crop Products in the Northern Part of Cameroon
}

\author{
Samomssa Inna ${ }^{1}$, Jiokap Nono Yvette ${ }^{1,}$, Kamga Richard ${ }^{2}$ \\ ${ }^{1}$ University Institute of Technology (IUT) of the University of Ngaoundere, Department of Chemical Engineering and Environment, \\ Ngaoundere, Cameroon \\ ${ }^{2}$ National Advanced School of Agro-Industrial Sciences (ENSAI) of the University of Ngaoundere, Department of Applied Chemistry, \\ Ngaoundere, Cameroon
}

Email address:

jiokapnonoy@yahoo.fr (J. N. Yvette)

\section{To cite this article:}

Samomssa Inna, Jiokap Nono Yvette, Kamga Richard. Energy Potential of Waste Derived from Some Food Crop Products in the Northern Part of Cameroon. International Journal of Energy and Power Engineering. Vol. 4, No. 6, 2015, pp. 342-352. doi: 10.11648/j.ijepe.20150406.13

\begin{abstract}
The purpose of this study was to quantify the agricultural crop productions in each division of the northern regions of Cameroon, to evaluate the proportion of waste derived from these and to classify them according to their potential as energy sources. To achieve these goals, statistical data from Cameroon's Ministry of Agriculture as well as standard methods of proximate analysis have been used to evaluate the proportion of each waste and its physico-chemical properties. The study reveals that agricultural activities generate an important quantity of waste (corn cobs and stalks, millet/sorghum stalks, rice hulls, cassava peelings, groundnut hulls, sweet potato peelings, Irish potato peelings and cotton hulls) of about 555002.27 dry-bone tons per annum in the three northern regions of Cameroon. The highest waste production is found in the North region with $42.93 \%$ of the total waste, directly followed by the Far North region with $42.44 \%$. Of the three regions, the Adamawa presents the smallest percentage $(11.23 \%)$. The main agro-industrial waste of these regions includes cotton hulls, with $3.41 \%$ of the total waste. The anhydrous low heating values of the wastes derived from the selected food crop products vary between 13.51 and $29.97 \mathrm{MJ} /(\mathrm{kg} \mathrm{d}-\mathrm{b})$, indicating a total biomass-energy potential in the northern part of Cameroon of $11.5 \mathrm{TJ}$ per year.
\end{abstract}

Keywords: Northern Regions of Cameroon, Food Crop Products, Lignocellulosic Waste, Heating Value, Bio-energy

\section{Introduction}

The energy deficit observed in the world is justified by urbanization and industrialization [1]. The principal sources of energy are divided into two groups: renewable and nonrenewable energy [2]. Among the nonrenewable energies, the most used are petrol oil, nuclear energy and gas [3]. These energies are not very available, exhaustive, very expensive especially for the rural populations and are sources of pollution [4]. Whereas, there are more available and less polluting and renewable energies, namely wind energy, hydropower, biomass and solar energy [4, 5].

However, in the less developed countries like Cameroon, wind energy, solar energy and hydropower are not very accessible. They use wood for their energy need [6], which leads to a fast deforestation and consequently to an acceleration of global warming $[4,7,8]$. In this context, cheap biomass in the form of agricultural residues stands as the most attractive and promising energy source for fuel, heat and electricity [8]. The choice of this biomass type however, as modern source of energy depends on their availability. In this regards, Ackom et al. [9] assessed the biomass resource potential in Cameroon which amounts to 1.11 million bone-dry tons per year. This study did not specify the proportion of crop residues generated by each region of the country. In the Northern part of Cameroon, no systematic study on the quantification and biomass analysis of agricultural-derived wastes has been performed to date.

The aim of this study is to quantify the agricultural products in the northern parts of Cameroon, to evaluate the proportion of waste by the types of crops grown in each division, and to classify them according to their potential use for bioenergy.

\section{Materials and Methods}

\subsection{Investigated Food Crop Products}

The food crop products investigated in this study are presented in Table 1. They are the most cultivated in the northern parts of Cameroon (more than $90 \%$ of the said region total production) [10]. 
Table 1. Agricultural products investigated.

\begin{tabular}{ll}
\hline Agricultural crop products & Scientific name [11, 12] \\
\hline Banana/plantain & Musa spp \\
Corn & Zea mays \\
Rice & Oryza sativa \\
Millet/Sorgho & Pennisetum spp/Sorghum Bicolor \\
Cassava & Manihot esculenta Crantz \\
Sweet Potato & Impomoea batatas \\
Yam & Dioscorea spp \\
Irish potato & Solanum Tuberosum \\
Groundnut & Arachis hypogaea \\
Cotton & Gossypium hirsutum \\
\hline
\end{tabular}

Among these agricultural products, some generate agricultural residues and others house hold wastes. For the present study the agricultural residues collected from the farms are corn cobs, corn stalks, sorghum/millet stalks, cassava peelings and groundnut hulls. Plantain peelings and stocks, sweet potato peelings, Irish potato peelings, yam peelings are the most produced household wastes and are collected by the Cameroon Waste Collection Society (HYSACAM). Cotton is transformed in industry and generates an industrial waste (cotton hulls). Corn is also transformed in industry (MAISCAM-Ngaoundere) and generates corn cobs and corn stalks as wastes.

\subsection{Analysis and Calculation Methods}

The agricultural productions data were collected from Cameroon's Ministry of Agriculture and Rural Development [13-15]. The generated waste of each food crop product (W) was calculated by the following equation, where $\mathrm{P}$ is the production tonnage of the food crop and RPR the residue to product ratio obtained by dividing the mass of waste in a sample by the mass of the corresponding sample:

$$
\mathrm{W}=\mathrm{P} \cdot \mathrm{RPR}
$$

Proximate analysis of different wastes was also investigated. Analyses were carried out on a mixture of two varieties frequently present in the locality (ratio 1:1). The waste moisture content was evaluated according to ASTM E1871-82 method [16], volatile matter (\%VM) by ASTM E872-82 method [17] and ash (\%ash) by ASTM E1755-01 method [18]. Fixed carbon percentage $(\% \mathrm{FC})$ was calculated by the following equation [19]:

$$
\% \mathrm{FC}=100-(\% \mathrm{ash}+\% \mathrm{VM})
$$

The lower heating value (LHV) expressed in $\mathrm{MJ} /(\mathrm{kg} \mathrm{w}-\mathrm{b})$ was determined using an oxygen bomb calorimeter (Parr 6100 Model A1329 DD, ID lot number M15320). Measurements were conducted on each sample previously dried in an oven at $45^{\circ} \mathrm{C}$ till constant weight corresponding to a moisture content MC\# (g/100g w-b). The anhydrous lower heating value
(ALHV) expressed in $\mathrm{MJ} /(\mathrm{kg} \mathrm{d}-\mathrm{b})$ was then calculated by the following equation:

$$
\mathrm{ALHV}=\mathrm{LHV} \cdot \frac{100}{100-\mathrm{MC} \#}
$$

ALHV was also expressed in $\mathrm{kWh} /(\mathrm{kg} \mathrm{d}-\mathrm{b})$ using the conversion factor:

$$
\frac{1 \mathrm{kWh} /(\mathrm{kg} \mathrm{d} . \mathrm{b})}{3.6 \mathrm{MJ} /(\mathrm{kg} \mathrm{d} \cdot \mathrm{b})}=1
$$

\subsection{Presentation of the Study Area}

Figure 1 shows the northern part of Cameroon, composed of fifteen divisions. From up to down the picture, we have the Far-North region with six divisions (Logone-et-Chari; Mayo-Sava; Mayo-Tsanaga ; Diamare; Mayo-Kani; Mayo-Danay) followed by the North region with four divisions (Mayo-Louti; Benoue; Faro; Mayo-Rey) and finally the Adamawa region with five divisions (Faro-et-Deo; Vina; Mayo-Banyo; Djerem; Mbere). Also presented on Table 2 are the area of each department and the area of arable land of the investigated food crops (average data 2013-2014). This table brings out that the northern part of Cameroon area is equal to $34.5 \%$ the total surface area of Cameroon [20].

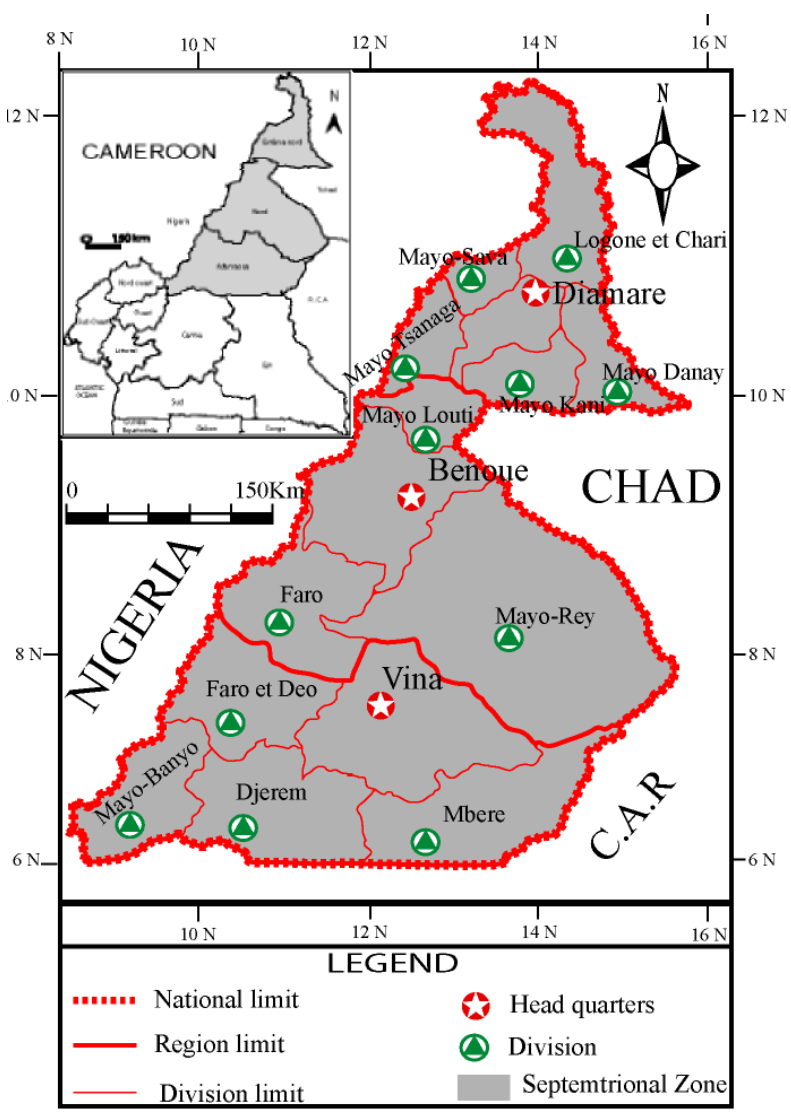

Figure 1. Location map of the study area. 
Table 2. Area of each department (ha) and area of arable land (ha) of the investigated food crops [13-15, 20].

\begin{tabular}{|c|c|c|c|c|c|c|c|c|c|c|c|}
\hline Division & Division Area & $\begin{array}{l}\text { Banana/ } \\
\text { Plantain }\end{array}$ & Corn & Cassava & Rice Area & Groundnut & $\begin{array}{l}\text { Millet/ } \\
\text { Sorghum }\end{array}$ & Potato & Yam & $\begin{array}{l}\text { Irish } \\
\text { potato }\end{array}$ & $\begin{array}{l}\text { Total arable } \\
\text { land }\end{array}$ \\
\hline Vina & 1719600.00 & 75.75 & 22682.50 & 12493.13 & 40.63 & 944.60 & 1230.60 & 1316.25 & 699.13 & 570.88 & 40053.45 \\
\hline Mbere & 1426700.00 & 165.13 & 2439.50 & 7004.75 & 0.00 & 1146.50 & 27.00 & 550.60 & 327.75 & 80.75 & 11741.98 \\
\hline Faro Edeo & 1043500.00 & 47.61 & 5585.15 & 1524.85 & 127.08 & 1873.01 & 7531.81 & 185.08 & 113.50 & 28.40 & 17016.48 \\
\hline Mayo Bayo & 852000.00 & 2197.00 & 15323.50 & 2726.00 & 218.00 & 2721.50 & 0.00 & 835.75 & 187.50 & 75.50 & 24284.75 \\
\hline Djerem & 1328300.00 & 297.25 & 8058.00 & 5783.00 & 0.00 & 5760.00 & 0.00 & 412.00 & 479.00 & 35.25 & 20824.50 \\
\hline Total area & & & & & & & & & & & \\
\hline $\begin{array}{l}\text { Adamawa } \\
\text { region }\end{array}$ & 6370100.00 & 2782.74 & 54088.65 & 29531.73 & 385.70 & 12445.61 & 8789.41 & 3299.68 & 1806.88 & 790.78 & 113921.15 \\
\hline Benoue & 1361400.00 & 300.00 & 66560.50 & 2008.50 & 9831.00 & 39584.00 & 88677.50 & 1600.00 & 2129.00 & 16.50 & 210707.00 \\
\hline Faro & 1178500.00 & 175.00 & 11300.00 & 1960.00 & 6250.00 & 38211.50 & 19025.00 & 1706.00 & 2256.00 & 0.00 & 80883.50 \\
\hline Mayo-Louti & 416200.00 & 325.00 & 32152.00 & 1850.00 & 601.50 & 38900.50 & 53086.50 & 1410.50 & 2730.50 & 0.00 & 131056.50 \\
\hline Mayo-Rey & 3652900.00 & 400.00 & 29250.00 & 2563.00 & 5500.00 & 41642.50 & 25000.00 & 2199.50 & 1402.00 & 0.00 & 107957.00 \\
\hline $\begin{array}{l}\text { Total area } \\
\text { North region }\end{array}$ & 6609000.00 & 1200.00 & 139262.50 & 8381.50 & 22182.50 & 158338.50 & 185789.00 & 6916.00 & 8517.50 & 16.50 & 530604.00 \\
\hline Diamare & 466500.00 & 0.00 & 7061.50 & 167.50 & 2385.00 & 8262.00 & 145508.00 & 1065.50 & 0.00 & 0.00 & 164449.50 \\
\hline $\begin{array}{l}\text { Logone and } \\
\text { Chary }\end{array}$ & 1213300.00 & 0.00 & 30445.80 & 442.90 & 10003.50 & 15.00 & 38394.50 & 600.15 & 0.00 & 0.25 & 79902.10 \\
\hline Mayo-Danay & 530300.00 & 0.00 & 4546.90 & 1877.15 & 10119.60 & 7762.25 & 106768.10 & 52.85 & 0.00 & 0.00 & 131126.85 \\
\hline Mayo-Kani & 503300.00 & 0.00 & 7960.00 & 423.50 & 454.50 & 4705.00 & 95182.50 & 83.50 & 0.00 & 0.00 & 108809.00 \\
\hline Mayo Sava & 273600.00 & 0.00 & 5162.50 & 13.50 & 470.45 & 8111.30 & 87352.20 & 11.00 & 0.00 & 0.00 & 101120.95 \\
\hline Mayo Tsanaga & 439300.00 & 0.00 & 55266.25 & 820.00 & 4418.50 & 53787.90 & 97148.65 & 1919.50 & 0.00 & 4226.10 & 217586.90 \\
\hline $\begin{array}{l}\text { Total area Far } \\
\text { North region }\end{array}$ & 3426300.00 & 0.00 & 110442.95 & 3744.55 & 27851.55 & 82643.45 & 570353.95 & 3732.50 & 0.00 & 4226.35 & 802995.30 \\
\hline $\begin{array}{l}\text { Total surface } \\
\text { area }\end{array}$ & 16405400.00 & 3982.74 & 303794.10 & 41657.78 & 50419.75 & 253427.56 & 764932.36 & 13948.18 & 10324.38 & 5033.63 & 1447520.45 \\
\hline
\end{tabular}

\section{Results and Discussion}

\subsection{Evolution of Agricultural Crop Production in the Northern Part of Cameroon}

Figures 2, 3 and 4 present the evolution of the selected agricultural products in Adamawa, North and Far North regions respectively.

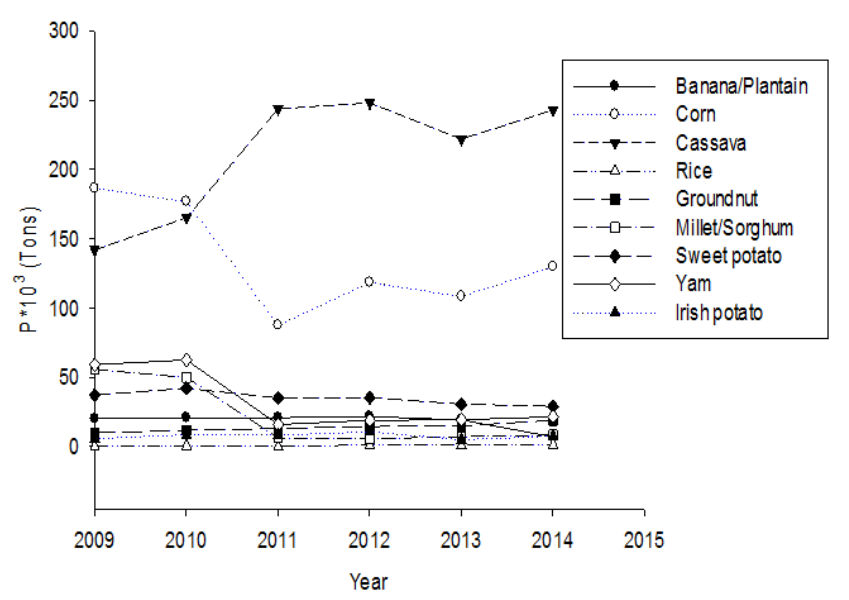

Figure 2. Evolution of selected agricultural crop products in the Adamawa region. $P$ is the production tonnage of the food crop.

The Figure 2 reveals that amongst the selected agricultural products, cassava presents a global increasing production over years and a highest production level followed by corn. Over the three last years $(2012,2013$ and 2014), cassava average production equals to $(238 \pm 14) \cdot 10^{3}$ tons. Between 2010 and 2011, corn production as well as yam and millet/sorghum productions significantly decreased due to poor technical know-how of cultivation techniques, non-readily accessible improved species and fertilizers, the non-use of fallowing techniques and the presence of food scavengers [21]. Since 2014 , there is a slight increase in corn production. The average corn production over the three years equals to $(119 \pm 11) \cdot 10^{3}$ tons. Rice production is the smallest amongst all with an average production of $1227 \pm 115$ tons over the three last years. All the other productions (banana/plantain, groundnut, sweet potatoes and Irish potatoes) have a substantial constant production since 2009 .

It appears on the Figure 3 that corn, millet/sorghum and groundnut are the most cultivated in the North region with an average production over the three last years of $(291 \pm 7) .10^{3}$; $(281 \pm 49) \cdot 10^{3}$ and $(241 \pm 5) \cdot 10^{3}$ tons respectively. Between 2012 and 2013, millet/sorghum production declined sharply due to seasonal changes and inefficient cultivation techniques [21]. For the other food crop products (rice, cassava, sweet potatoes, yam, banana/plantain and Irish potatoes), productions are smaller and vary between $(52 \pm 5) \cdot 10^{3}$ tons for rice to $57 \pm 6$ tons for Irish potatoes. The smallest production of the latter has been decreasing over the years due to plant 
pest diseases like Phytophthora infestans and Ralstonia solanacearum [21] as well as the lack of improved varieties of the local species. Most of the selected products have increasingly evolved since 2009 with the advent of agricultural research and development by scientific institutes such as the Institute of Research and Agricultural Development (IRAD-Cameroon).

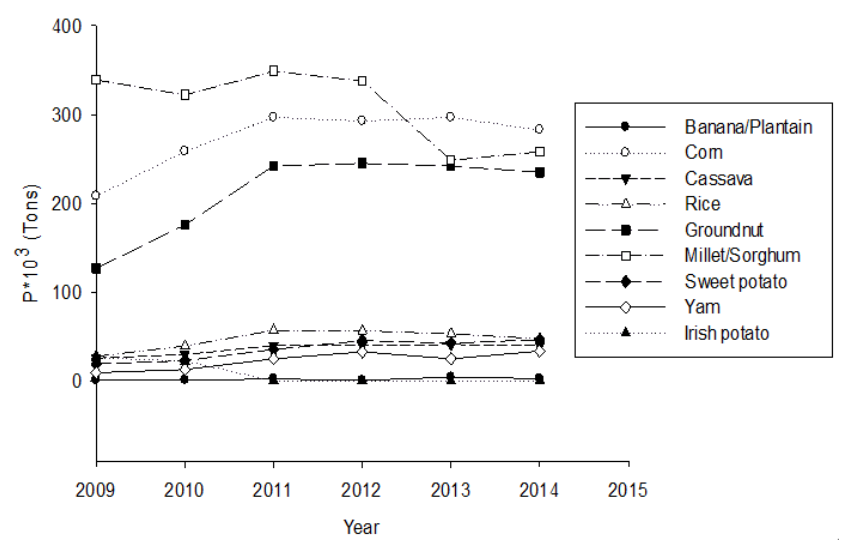

Figure 3. Evolution of selected agricultural crop products in the North region.

The Figure 4 shows that sorghum/millet has the highest production in the Far-North region. The average production over the three last years is $(803 \pm 147) \cdot 10^{3}$ tons. This production increased from 2009 and 2012, but a sharp decrease was observed between 2012 and 2014.

Other crops like corn, groundnut, rice, sweet potatoes, cassava and Irish potatoes are less produced. In this group, the lowest production is recorded on Irish potatoes and the highest on corn. For these two, productions increased over the three last years, to reach an average of $(38 \pm 32) \cdot 10^{3}$ tons for Irish potatoes and $(208 \pm 42) \cdot 10^{3}$ tons for corn. For the remaining food crop products (groundnut, rice, sweet potatoes, cassava), the production is almost constant since 2009. However, it can be noticed that yam and banana/plantain are not produced in the Far-North region.

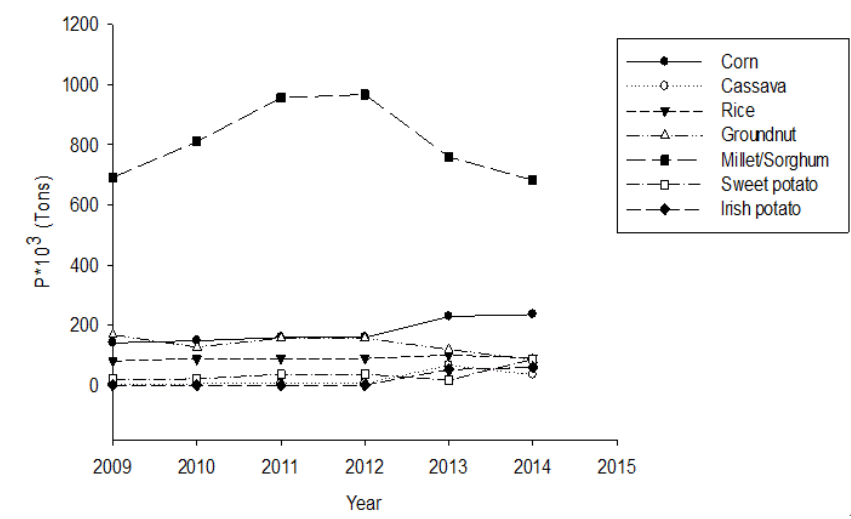

Figure 4. Evolution of selected agricultural crop products in the Far-North region.

\subsection{Proximate Analysis of Waste Generated in the Northern Part of Cameroon}

Table 3 presents the proximate analysis of some wastes generated in the northern parts of Cameroon. As indicated by Vargas-Moreno et al. [22] and Lee and Shah [23], the compositional information provides the science and engineering information needed to predict the feedstock behavior in a processing, and much more.

Table 3. Proximate analysis of different wastes.

\begin{tabular}{|c|c|c|c|c|c|c|c|c|}
\hline Waste & $\begin{array}{l}\text { MC } \\
(\mathrm{g} / 100 \mathrm{~g} w-b)\end{array}$ & $\begin{array}{l}\text { VM } \\
(g / 100 g d-b)\end{array}$ & $\begin{array}{l}\text { Ash } \\
(\mathrm{g} / 100 \mathrm{~g} d-b)\end{array}$ & $\begin{array}{l}\text { FC } \\
(g / 100 g d-b)\end{array}$ & $\begin{array}{l}\text { LHV } \\
\text { MJ/(kg w-b) }\end{array}$ & $\begin{array}{l}\text { MC\# } \\
(\mathrm{g} / 100 \mathrm{~g} w-b)\end{array}$ & $\begin{array}{l}\text { ALHV } \\
\text { MJ/(kg d-b) }\end{array}$ & $\begin{array}{l}\text { ALHV } \\
\text { kWh/(kg d-b) }\end{array}$ \\
\hline Corn cobs & $12.00 \pm 0.23$ & $98.67 \pm 0.28$ & $0.92 \pm 0.14$ & $0.41 \pm 0.02$ & $25.33 \pm 0.03$ & $7.33 \pm 0.29$ & 27.33 & 7.59 \\
\hline $\begin{array}{l}\text { Millet/ Sorghum } \\
\text { stalks }\end{array}$ & $10.00 \pm 0.12$ & $94.17 \pm 1.89$ & $2.65 \pm 0.93$ & $3.19 \pm 0.96$ & $15.4 \pm 0.02$ & $8.83 \pm 0.29$ & 16.89 & 4.69 \\
\hline $\begin{array}{l}\text { Banana/plantain } \\
\text { peelings and } \\
\text { stocks }\end{array}$ & $89.00 \pm 0.98$ & $78.17 \pm 3.18$ & $6.26 \pm 0.98$ & $15.58 \pm 7.35$ & $17.51 \pm 0.02$ & $12.67 \pm 5.48$ & 20.05 & 5.57 \\
\hline Cassava peelings & $75.50 \pm 0.35$ & $90 \pm 2.83$ & $4.52 \pm 0.793$ & $5.48 \pm 1.90$ & $12.52 \pm 0.01$ & $7.33 \pm 0.29$ & 13.51 & 3.75 \\
\hline Rice hulls & $9.00 \pm 0.49$ & $70.83 \pm 4.37$ & $11.07 \pm 2.14$ & $18.10 \pm 2.79$ & $16.41 \pm 0.02$ & $8 \pm 0.50$ & 17.84 & 4.95 \\
\hline Groundnut hulls & $8.00 \pm 0.50$ & $74.67 \pm 1.26$ & $8.56 \pm 0.56$ & $16.77 \pm 1.24$ & $18.13 \pm 0.02$ & $9.50 \pm 0.86$ & 20.03 & 5.56 \\
\hline $\begin{array}{l}\text { Sweet potato } \\
\text { peelings }\end{array}$ & $75.95 \pm 0.42$ & $69.75 \pm 3.18$ & $0.85 \pm 0.05$ & $29.40 \pm 3.71$ & $25.03 \pm 0.03$ & $10.50 \pm 0.10$ & 27.97 & 7.77 \\
\hline $\begin{array}{l}\text { Irish potato } \\
\text { peelings }\end{array}$ & $83.00 \pm 0.92$ & $93.00 \pm 1.50$ & $3.29 \pm 0.60$ & $3.71 \pm 1.01$ & $25.77 \pm 0.03$ & $14 \pm 0.50$ & 29.97 & 8.32 \\
\hline Yam peelings & $73.00 \pm 0.17$ & $91.00 \pm 3.54$ & $1.88 \pm 0.53$ & $7.12 \pm 3.01$ & $18.32 \pm 0.02$ & $13.83 \pm 0.29$ & 21.26 & 5.91 \\
\hline Cotton hulls & $9.00 \pm 0.02$ & $81.13 \pm 2.62$ & $14.51 \pm 0.30$ & $4.36 \pm 0.36$ & $16.57 \pm 0.02$ & $9.00 \pm 0.02$ & 18.21 & 5.06 \\
\hline
\end{tabular}

With MC the wet-basis moisture content of raw waste; VM the volatile mater; FC the fixed carbon; MC\# the wet-basis moisture content of $45^{\circ} \mathrm{C}$ oven-dried raw waste; LHV the low heating value; ALHV the anhydrous low heating value. 
From the Table 3, the moisture content of the different studied wastes can be categorized into 2 groups. The first group is composed of high moisture content wastes (banana/plantain peelings and stocks; cassava peelings; sweet potato peelings, Irish potato peelings and yam peelings) and the second group is composed of less humid wastes (corn cobs and stalks; millet stalks; rice hulls; groundnut hulls and cotton hulls). Most produced wastes belong to this last group. Values of volatile matter (VM), ash and fixed carbon (FC) vary respectively between $69.75 \%$ for sweet potato peelings and $98.67 \%$ for corn cobs; $0.85 \%$ for sweet potato peelings and $6.26 \%$ for banana/plantain peelings and stocks; $0.42 \%$ for corn cobs and $29.4 \%$ for sweet potato peelings. According to Vargas-Moreno et al. [22] and Debdoubi et al. [24], the higher the volatile matter and the fixed carbon contents, the higher the heating values. Also, the higher the ash content, the lower the heating value. One can therefore expect a high heating value for corn cobs, sweet potato peelings and Irish potato peelings compared to other crop wastes. This is confirmed by the heating values obtained by the bomb calorimeter and presented in the same table. Except for the cassava peelings, all the obtained heating values are greater than $4 \mathrm{kWh} / \mathrm{kg} \mathrm{d}-\mathrm{b}$ ). ADEME [25] mentioned that the anhydrous heating value of hardwood is between 4.8 and $5.3 \mathrm{kWh} / \mathrm{kg}$. Our results reveal that the studied wastes have heating values comparable to that of wood and can therefore be used as substituents to wood-energy.

Proximate analysis results for banana/plantain peelings show that our result for fixed carbon and volatile matter contents are in accordance with those obtained by Bianca et al. [26]. Concerning the heating values, our result is similar to those presented in the literature, ranging from $9.76 \mathrm{MJ} / \mathrm{kg}$ to $17.30 \mathrm{MJ} / \mathrm{kg}[26,27]$. However, from literature, the ash content data range from $9.51 \%$ to $15.3 \%$ [26-28] and are not in accordance with our result, probably due to the differences in species of varieties used.

Concerning corn cobs, data in the literature range from $1 \%$ to $2.65 \%$ for ash content [29-31]; $8.25 \%$ to $18.54 \%$ for fixed carbon; $78.70 \%$ to $90.12 \%$ for volatile matter [31-33] and 6.79 to $26.3 \mathrm{MJ} / \mathrm{kg}$ for heating values $[27,29,34]$. The literature data for corn cobs are in accordance with our results. Corn stalks moisture content obtained is $(10.00 \pm 0.23) \mathrm{g} /(100 \mathrm{~g} \mathrm{w}-\mathrm{b})$; however, volatile matter, ash, fixed carbon contents and low heating value were not carried out in this study. Respective values in the literature are $59.83 \% ; 11.52 \% ; 17.00 \%$ and 16.29 $\mathrm{MJ} / \mathrm{kg}[35]$.

Literature data for yam peelings proximate analysis range from $3.27 \%$ to $14.50 \%$ for fixed carbon [36]; 15.54 to 16.43 $\mathrm{MJ} / \mathrm{kg}$ for heating value $[27,37]$ and $3.86 \%$ to $6.3 \%$ for ash content [27, 36]. Oladeji [36] obtained a volatile matter content of $82.87 \%$ for this substrate. Our heating value, volatile matter and ash content value are slightly different from those of the literature and could be due to the differences in the varieties used and the soil type.

Proximate analysis data for cassava peelings in the literature range from $3.25 \%$ to $8 \%$ for ash content $[27,38]$ and
12 to $16.32 \mathrm{MJ} / \mathrm{kg}$ for heating value [27]. Oladeji [36] obtained a volatile matter and fixed carbon content of $83.06 \%$ and $2.27 \%$ respectively. These are in accordance with our results.

For groundnut hulls, literature proximate analysis data range from $0.76 \%$ to $5.70 \%$ for ash content; $6.47 \%$ to $21.60 \%$ for fixed carbon; $72.70 \%$ to $88.47 \%$ for volatile matter and 19.20 to $13.78 \mathrm{MJ} / \mathrm{kg}$ for heating value $[36,37,39]$. These are in accordance with our results.

Rice hulls proximate analysis data in the literature range from $15.5 \%$ to $20.26 \%$ for ash content $[29,40] ; 63.52 \%$ to $90 \%$ for volatile matter $[40,41]$ and 12.1 to $16.7 \mathrm{MJ} / \mathrm{kg}$ for heating value [42]. These are in accordance with our results.

Proximate analysis of millet stalks and sorghum stalks in the literature are evaluated separately and values vary between $8.40 \%$ to 14.15 for ash content; $71.40 \%$ to $78.26 \%$ for volatile matter and 14.50 to 16.45 for fixed carbon [29, 30]. These authors also reported a heating value of $15.4 \mathrm{MJ} / \mathrm{kg}$. Our obtained values are in these intervals.

For cotton hulls, literature proximate analysis data vary between $1.61 \%$ to $5.10 \%$ for ash content; $77.80 \%$ to $83.41 \%$ for volatile matter; $14.97 \%$ to $17.10 \%$ for fixed carbon and 18.13 to $18.28 \mathrm{MJ} / \mathrm{kg}$ for heating value $[29,40,41]$. These are in accordance with our results.

Concerning sweet potato peelings and Irish potato peelings, the literature values for volatile matter content are $75 \%$ and $90 \%$ respectively [41]. Our obtained values slightly differ from these.

\subsection{Quantification of Waste Generated in the Northern Part of Cameroon}

Table 4 presents the quantification (mean value over 2013 and 2014) of waste obtained in the northern part of Cameroon. Quantification is done using the total production over the three regions (Adamawa, North and Far-North) of the defined product and the residue to product ratio (RPR) as presented in section 2. Values are compared to the national production available by now (average for the year 2010).

The Table 4 shows that in the northern parts of Cameroon, millet/sorghum is the most produced (982 025.39 tons), followed by corn. Banana/plantain is the less produced (16 542. 05 tons) and this could be due to climatic conditions which are not well adapted to this crop. For the selected agricultural crop products, the annual total production is around 2188213.87 tons for the northern parts of Cameroon corresponding to $17.88 \%$ of the national production.

Many estimates of the residue to product ratio (RPR) of the different studied crops are reported in the literature and there are significant differences among them. RPR values of corn cobs in the literature range from $20 \%$ to $30 \%$ for sample moisture content between 7.53 to $15 \%[43,44]$. Our obtained value is in this range. However, Lacour et al. [41] mentioned a RPR of $500 \%$ for a sample moisture content of $85 \%$. Concerning corn stalks, the values range from $40 \%$ to $432.8 \%$ $[41,45]$. Our obtained value of $13 \%$ is not in this range and could be justified by differences in moisture content and the corn variety. 
Table 4. Annual quantification of waste derived from selected agricultural crop products in the northern part of Cameroon.

\begin{tabular}{|c|c|c|c|c|c|c|c|c|}
\hline \multicolumn{3}{|c|}{ Food crop products production (tons) } & \multicolumn{6}{|c|}{ Waste production (tons) } \\
\hline \multirow{2}{*}{$\begin{array}{l}\text { Food crop } \\
\text { products }\end{array}$} & \multirow{2}{*}{$\begin{array}{l}\text { Northern region } \\
\text { [13-15] }\end{array}$} & \multirow[b]{2}{*}{ National [10] } & \multirow[b]{2}{*}{ Waste generated } & \multirow[b]{2}{*}{ RPR (\%) } & \multicolumn{2}{|c|}{ Northern region } & \multicolumn{2}{|l|}{ National } \\
\hline & & & & & Wet tons & $\begin{array}{l}\text { Dry-bone } \\
\text { tons }\end{array}$ & Wet tons & Dry-bone tons \\
\hline \multirow{2}{*}{ Corn } & \multirow{2}{*}{641211.07} & \multirow{2}{*}{1647767.00} & Corn cobs & $25 \pm 1$ & 160302.77 & 141066.44 & 411941.75 & 362508.74 \\
\hline & & & Corn stalks & $13 \pm 1$ & 83357.44 & 75021.70 & 214209.71 & 192788.74 \\
\hline Millet/Sorghum & 982025.39 & 1166533.50 & Millet/Sorghum stalks & $14 \pm 1$ & 137483.56 & 123735.20 & 163314.69 & 146983.22 \\
\hline Banana/plantain & 16542.05 & 4249110.50 & $\begin{array}{l}\text { Banana/plantain } \\
\text { peelings and stocks }\end{array}$ & $40 \pm 4$ & 6616.82 & 727.85 & 1699644.20 & 186960.86 \\
\hline Cassava & 324449.80 & 3574400.50 & Cassava peelings & $20 \pm 1$ & 64889.96 & 15898.04 & 714880.10 & 175145.62 \\
\hline Rice & 147406.62 & 143868.50 & Rice hulls & $20 \pm 1$ & 29481.32 & 26828.00 & 28773.70 & 26184.07 \\
\hline Groundnut & 357161.20 & 519681.00 & Groundnut hulls & $43 \pm 1$ & 153579.32 & 141292.97 & 223462.83 & 205585.80 \\
\hline Sweet potato & 147135.11 & 277524.00 & Sweet potato peelings & $20 \pm 1$ & 29427.02 & 7077.20 & 55504.80 & 13348.90 \\
\hline Irish potato & 62577.75 & 177612.00 & Irish potato peelings & $27 \pm 3$ & 16895.99 & 2872.32 & 47955.24 & 8152.39 \\
\hline Yam & 49615.95 & 483156.50 & Yam peelings & $12 \pm 2$ & 5853.91 & 1580.56 & 57978.78 & 15654.27 \\
\hline Cotton & 101300.00 & 101300.00 & Cotton hulls* & l & 20771.43 & 18902.00 & 20771.48 & 18902.00 \\
\hline Total : & 2188213.87 & 12239653.50 & / & / & 708659.53 & 555002.27 & 3638437.23 & 1352214.62 \\
\hline
\end{tabular}

*: Industrial waste.

The RPR for rice hulls in the literature ranges from $20 \%$ to $33 \%$ for $2.37 \%$ sample moisture content $[44,46]$ and our value is within this range. Lacour et al. [41] mentioned a RPR value of $500 \%$ for $50 \%$ rice hulls moisture content. Similar observations were made for millet stalks and sorghum stalks whose literature values vary between $100 \%$ to $200 \%$ and $90 \%$ to $500 \%$ respectively $[41,44]$. These reports indicate the high dependency of RPR to the waste moisture content.

For cassava peelings, Koopmans and Koppejan [44] reported a RPR value of 2 to $3 \%$ for a sample moisture content of 50. Lacour et al. [41] reported a RPR value for cassava peelings of about $60 \%$. Our value of $20 \%$ is different and could be explained by differences in moisture content.

The value of RPR of groundnut hulls in the literature ranges from $47.7 \%$ to $50 \%$ for $8.2 \%$ sample moisture content [44, 45 , 47]. Our obtained value of $43 \%$ is slightly different from these values. Differences observed could be due to variability in crop species and soil types [48] and to the waste moisture content. Also, Lacour et al. [41] mentioned a RPR value of groundnut hulls of $200 \%$ for $50 \%$ moisture content.

In the literature, the residual ratios for banana/plantain, sweet potato, yam and Irish potato peelings are respectively $30 \%, 60 \%, 60 \%$ and $50 \%$ [11]. Our values are different and could be explained by moisture content variations and the peeling method used.
The Table 4 also indicates a total amount of waste generated in terms of wet basis and dry basis of about 708659.53 and 555002.27 tons respectively. These values correspond to waste global moisture content of $21.68 \%$. Among the estimated waste (dry basis), corn waste (corn cobs and corn stalks), groundnut hulls and millet/sorghum stalks present larger waste proportion in the Northern region of Cameroon. Their respective productions are $216088.14 ; 141292.97$ and 123735.20 dry-bone tons respectively, corresponding globally to $86.69 \%$ of the total waste. Sweet potato, Irish potato, yam and banana/plantain peelings are the less produced and represent a respective tonnage of $7077.20 ; 2$ $872.32 ; 1580.56$ and 727.85 dry-bone tons corresponding globally to $2.21 \%$ of the total waste. These four last are the essential house-hold wastes in the northern Cameroon. The remaining percentage (11.10\%) is distributed among rice hulls, cotton hulls and cassava peelings with respective values of 26 828; 18902 and 15898 dry-bone tons. The northern waste production, dry basis, represents $41.04 \%$ of the national waste production. The same trend is observed in terms of wet mass basis, with the northern waste production representing $19.48 \%$ of the national waste production (Table 5). However, on this basis, plantain/banana and yam waste generation is lower. The others such as rice hulls, sweet potato peelings, cotton hulls and Irish potato peelings have almost equal waste proportions.

Table 5. Comparison between northern and national productions.

\begin{tabular}{llll}
\hline \multirow{2}{*}{ Annual production } & Total agricultural production & \multicolumn{2}{l}{ Total waste-derived production } \\
\cline { 3 - 4 } & & Wet tons & Waste weighted \\
moisture content & 708659.53 & 555002.27 \\
Northern parts & 2188213.87 & 3638437.23 & 1352214.62 \\
National & 12239653.50 & 19.48 & 41.04 \\
Northern parts/ National (\%) & 17.88 & 62.84 & $/$ \\
\hline
\end{tabular}


This table shows that almost the fifth of national agricultural production is found in the northern parts of Cameroon. It can also be noticed that the global moisture content of national total waste is 2.9 times greater than the one of the northern parts. This difference is especially due to banana/plantain peelings and stocks production, which is greater in the south parts of Cameroon and which is having the higher moisture content. However, more than the two-fifth of national waste production, dry basis, is recorded in the northern part.

\subsection{Energy Potential of Investigated Wastes}

Table 6 presents the annual energy potential of the investigated wastes. The total calorific value of the investigated wastes is around $11.5 \mathrm{TJ}$ in the northern parts of Cameroon against 27.9 TJ for the national generated wastes. The energy potential of each waste follows the corresponding dry-bone tone production presented in the previous section. Amongst the investigated wastes, the major waste contributing to the total potential energy are corn waste (corn cobs and corn stalks), groundnut hulls and millet/sorghum stalks. Their respective contributions in the northern part of Cameroon are $45.31 \% ; 24.61 \%$ and $18.17 \%$ respectively corresponding globally to $88.09 \%$ of the total energy potential of the northern part. The national respective values are $48.05 \% ; 14.78 \%$ and $8.91 \%$ corresponding globally to $71.74 \%$ of the national studied waste total potential energy.

Table 6. Energy potential of wastes in terms of type in the northern region compared to national values.

\begin{tabular}{lllll}
\hline & \multicolumn{2}{l}{ Total energy (MJ) } & \multicolumn{2}{l}{ Total energy (kWh) } \\
\hline Waste & $\begin{array}{l}\text { Northern } \\
\text { region }\end{array}$ & National & $\begin{array}{l}\text { Northern } \\
\text { region }\end{array}$ & National \\
\hline Corn cobs & $3.86 \mathrm{E}+06$ & $9.91 \mathrm{E}+06$ & $1.07 \mathrm{E}+06$ & $2.75 \mathrm{E}+06$ \\
Corn stalks & $1.35 \mathrm{E}+06$ & $3.48 \mathrm{E}+06$ & $3.76 \mathrm{E}+05$ & $9.67 \mathrm{E}+05$ \\
Millet/sorghum stalks & $2.09 \mathrm{E}+06$ & $2.48 \mathrm{E}+06$ & $5.81 \mathrm{E}+05$ & $6.90 \mathrm{E}+05$ \\
Banana/plantain & $1.46 \mathrm{E}+04$ & $3.75 \mathrm{E}+06$ & $4.05 \mathrm{E}+03$ & $1.04 \mathrm{E}+06$ \\
peelings and stocks & $2.15 \mathrm{E}+05$ & $2.37 \mathrm{E}+06$ & $5.97 \mathrm{E}+04$ & $6.57 \mathrm{E}+05$ \\
Cassava peelings & $4.79 \mathrm{E}+05$ & $4.67 \mathrm{E}+05$ & $1.33 \mathrm{E}+05$ & $1.30 \mathrm{E}+05$ \\
Rice hulls & $2.83 \mathrm{E}+06$ & $4.12 \mathrm{E}+06$ & $7.86 \mathrm{E}+05$ & $1.14 \mathrm{E}+06$ \\
Groundnut hulls & $1.98 \mathrm{E}+05$ & $3.73 \mathrm{E}+05$ & $5.50 \mathrm{E}+04$ & $1.04 \mathrm{E}+05$ \\
Sweet potato peelings & $8.61 \mathrm{E}+04$ & $2.44 \mathrm{E}+05$ & $2.39 \mathrm{E}+04$ & $6.79 \mathrm{E}+04$ \\
Irish potato peelings & $3.36 \mathrm{E}+04$ & $3.33 \mathrm{E}+05$ & $9.33 \mathrm{E}+03$ & $9.24 \mathrm{E}+04$ \\
Yam peelings & $3.44 \mathrm{E}+05$ & $3.44 \mathrm{E}+05$ & $9.56 \mathrm{E}+04$ & $9.56 \mathrm{E}+04$ \\
Cotton hulls & $1.15 \mathrm{E}+07$ & $2.79 \mathrm{E}+07$ & $3.19 \mathrm{E}+06$ & $7.74 \mathrm{E}+06$ \\
\hline TOTAL & & & & \\
\hline
\end{tabular}

\subsection{Waste Distribution in the Northern Part of Cameroon}

\subsubsection{Banana/Plantain Peelings and Stocks Distribution}

Figure 5 presents banana/plantain waste production in nine divisions of the northern parts of Cameroun. In the six divisions of the Far-North region, banana/plantain is not cultivated. This explains the very low aforementioned quantity of banana/plantain waste generated as compared to the other agricultural crops.

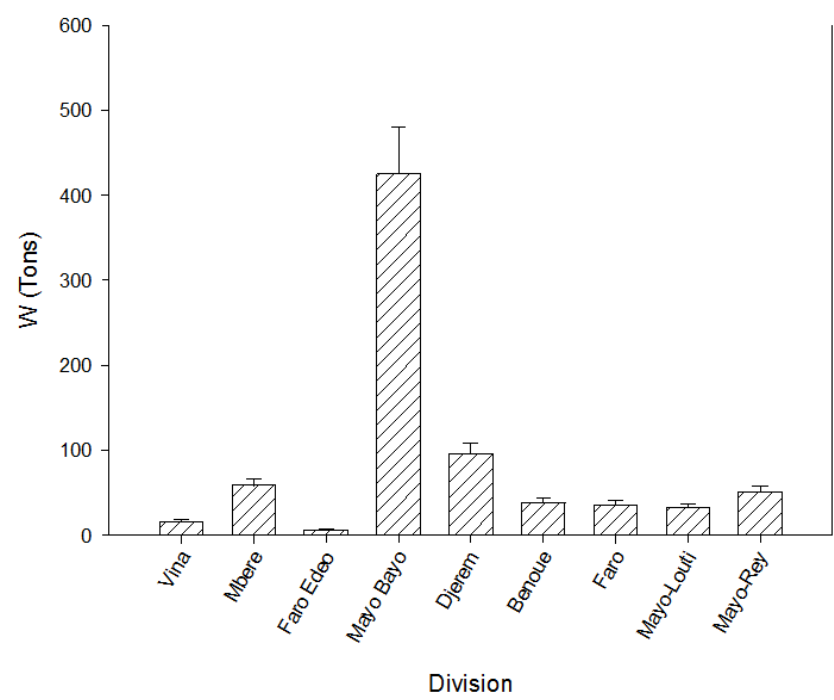

Figure 5. Generation of banana/plantain waste.

The Figure 5 reveals that banana/plantain waste is more generated in the Mayo Bayo division than in the others, where the generation is low with some slight variation from one division to another.

However, there is a significant quantity of plantain which enters Adamawa region by railway. This quantity was around 10890 tons (wet basis) between 2013 and 2014. That is without counting the quantity which enters this region by road. The corresponding wet tons and dry-bone tons of the waste generated are respectively 4356 and 479 tons. This value is more than the half of the banana/plantain waste generated in the northern part of Cameroon.

\subsubsection{Corn Cobs and Stalks Distribution}

Corn waste production is presented on Figure 6.

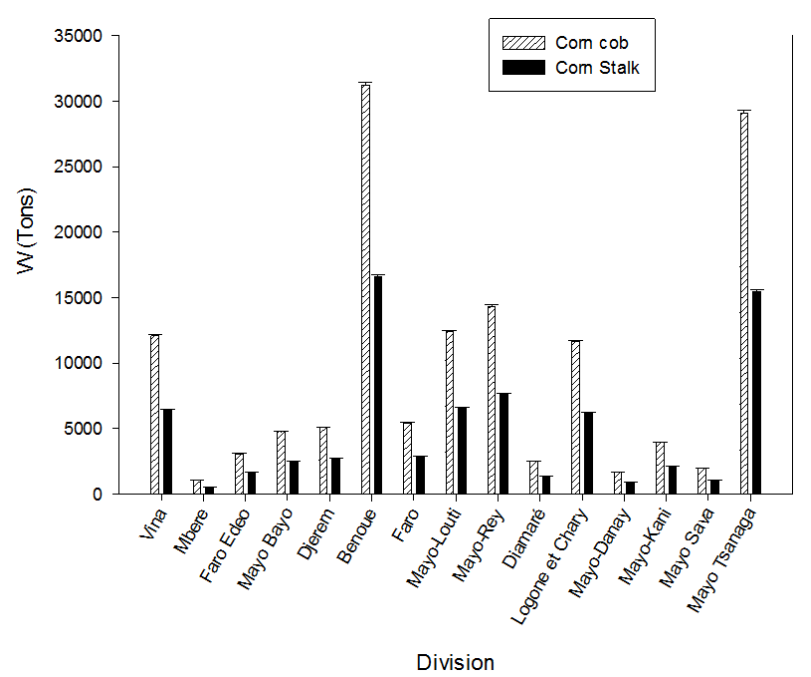

Figure 6. Corn cobs and corn stalks dry-bone tons generation.

From the Figure 6, it appears that the corn cobs fraction is always greater than that of the corn stalks. It is also observed that the tonnage of corn stalks and cobs is the highest in 
Benoue division (North region) and Mayo Tsanaga division (Far-North region). These are followed by the Vina division (Adamawa region), Mayo-Rey, Mayo-Louti (North region) and Logone and Chary (Far-North region) with almost an equal waste production. The waste proportions in the other divisions are low and present slight variations between them.

\subsubsection{Cassava Peelings Distribution}

The tonnage of the cassava peelings in the various areas of the Far-North is presented on Figure 7.

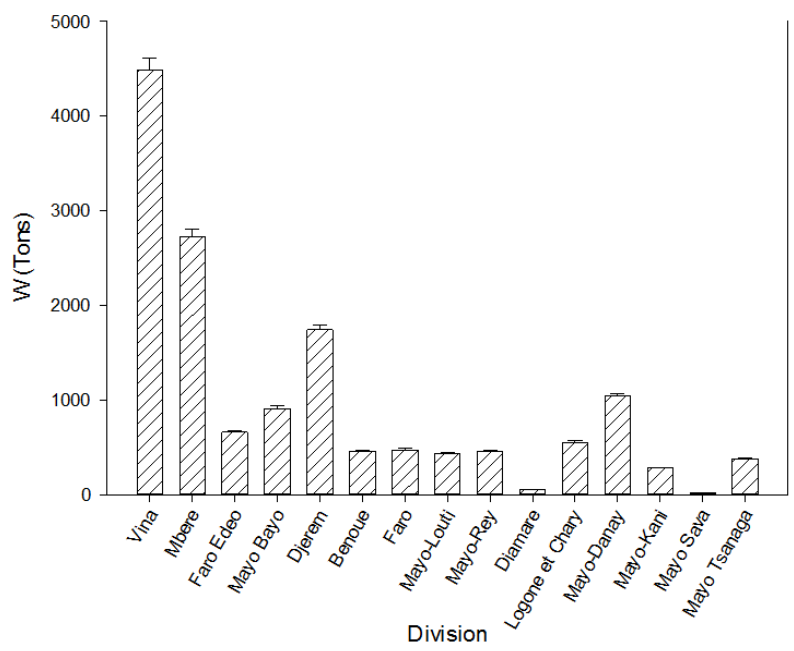

Figure 7. Cassava peelings dry-bone tons generation.

Cassava peelings in the Vina division presents the highest generation followed by Mbere and Djerem divisions. The lowest tonnage of cassava peelings is recorded in Mayo Sava and Diamare divisions. The tonnage of the other divisions is small and slightly equal.

\subsubsection{Rice Hulls Distribution}

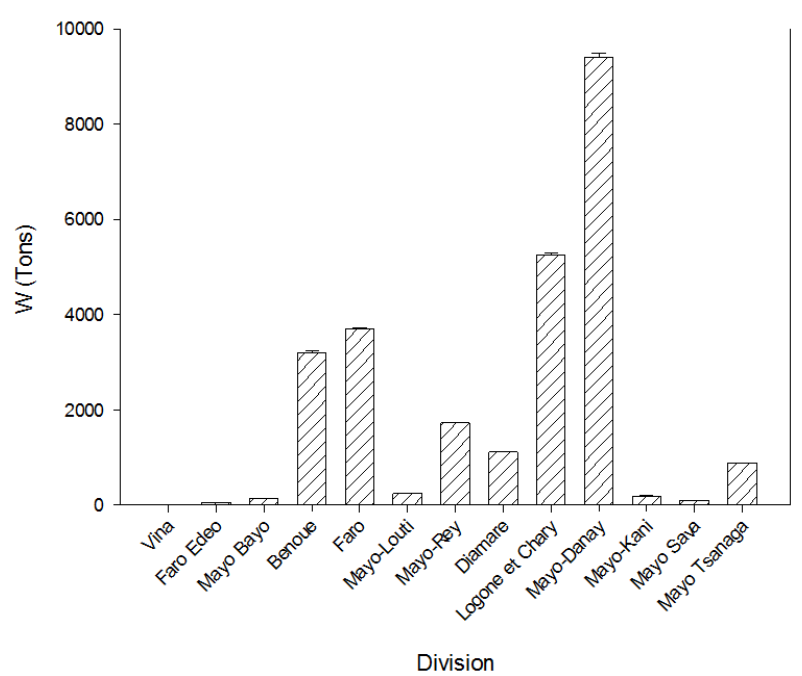

Figure 8. Rice hulls dry-bone tons generation.

Results are given on Figure 8. The Mayo-Danay division (Far-North region) stands out from other divisions with the highest rice hulls production, followed by Logone and Chary
(Far-North region), then by the Faro and Benoue division (North region). A lower generation of rice hulls is observed in the Adamawa region as compared to the North and Far-North regions. The generation in the other divisions is less with slight variation between them. It can be noticed that Djerem and Mbere divisions didn't cultivate this food crop during the year 2013 and 2014.

\subsubsection{Groundnut Hulls Distribution}

Groundnut hulls generation is presented on Figure 9. This figure shows that the Mayo Tsanaga division (Far-North region) has the highest tonnage of groundnut hulls, followed by those of Benoue, Faro, Mayo-Louti and Mayo-Rey division (North region). The productions recorded in Diamare, Logone and Chary, Mayo-Danay, Mayo-Kani and Mayo-Sava division (Far-North region) are low and the lowest proportion is found in the Adamawa region.

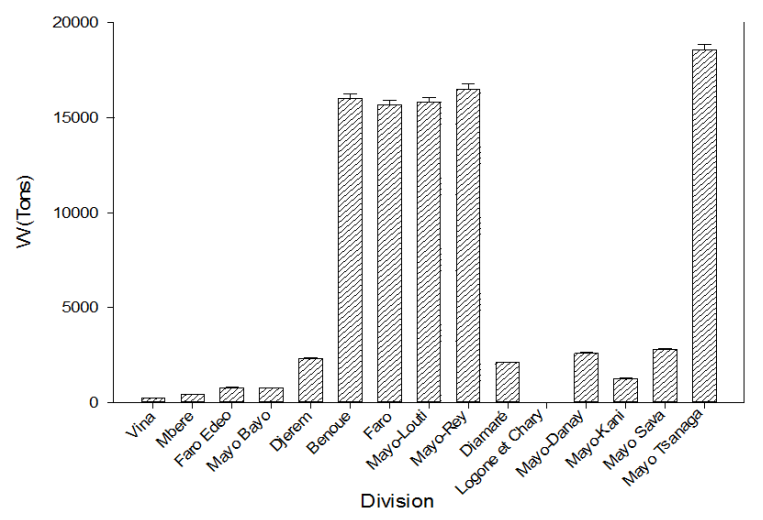

Figure 9. Groundnut hulls dry-bone tons generation.

\subsubsection{Sorghum/Millet Waste Distribution}

Figure 10 presents the production of the millet/sorghum stalks in thirteen divisions of the northern region of Cameroon. Djerem and Mayo Bayo do not cultivate this food crops.

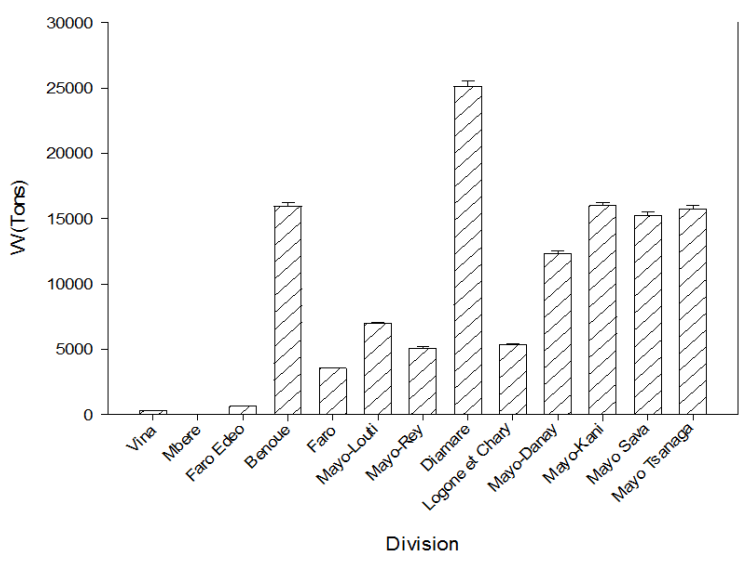

Figure 10. Sorghum/millet stalks dry-bone tons generation.

It is clear from this figure that the tonnage of millet/sorghum stalks is higher in Diamare division (Far-North region), followed by the tonnage of Mayo-Kani, Mayo-Tsanaga, Mayo-Sava Mayo-Danay division (Far-North region) and Benoue (North region). The lowest tonnage of 
Millet/sorghum stalks is found in Mbere, Vina and Faro Edeo (Adamawa division).

\subsubsection{Sweet Potato Peelings Distribution}

Production of sweet potato peelings in the northern parts of Cameroon (Figure 11) reveals that this waste proportion is the highest in Mayo Tsanaga, followed by Logone and Chary division (Far-North region) and Vina division (Adamawa region). The smallest productions are recorded in the Far-North region, especially in Mayo- Sava, Mayo-Danay and Mayo-Kani divisions. There is an average and slightly equal tonnage of sweet potato peelings in the other divisions.

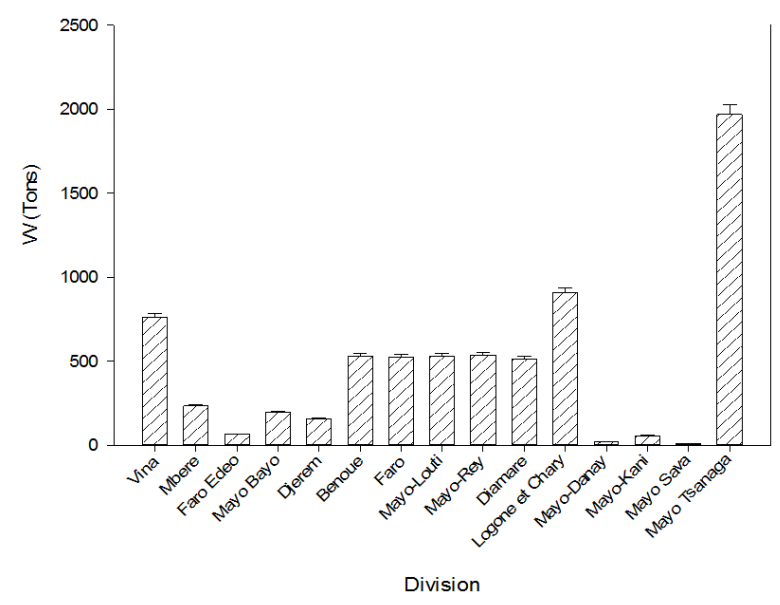

Figure 11. Sweet potatoes peelings dry-bone tons generation.

\subsubsection{Yam Peelings Distribution}

Results obtained in nine divisions of the Northern region are presented on Figure 12. We observe an almost equal tonnage of yam peelings in the various divisions. However, the lowest productions are recorded in Mayo Bayo and Faro Edeo divisions. This food crop is not cultivated in the Far-North region composed of six divisions (Diamare, Mayo Danay, Mayo Sava, Mayo Kani, Logone and Chary and Mayo Tsanaga).

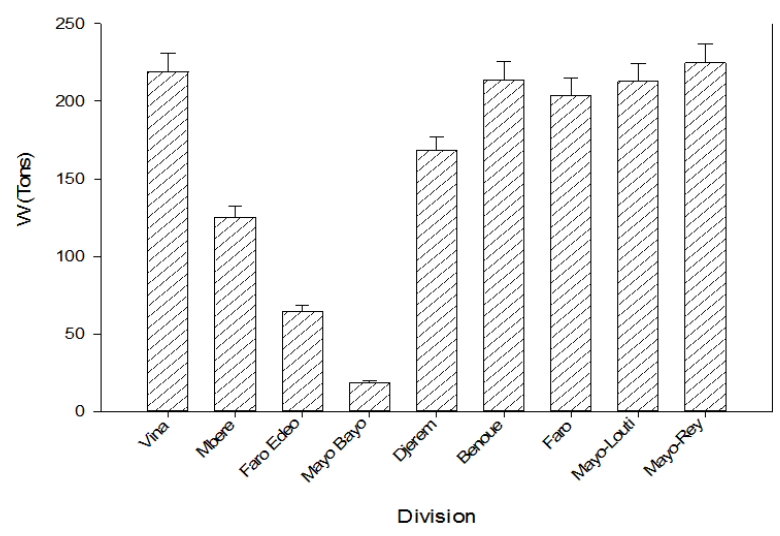

Figure 12. Yam peelings dry-bone tons generation.

\subsubsection{Irish Potato Peelings Distribution}

Figure 13 presents the tonnage of the potato peelings in the various divisions of Adamawa, North and Far-North regions. Amongst the fifteen divisions of this study area, a noticeable production is only depicted in Mayo-Tsanaga division (Far-North region), where the highest production is found, and in the Vina division (Adamawa region). The proportions recorded in the other division are very low.

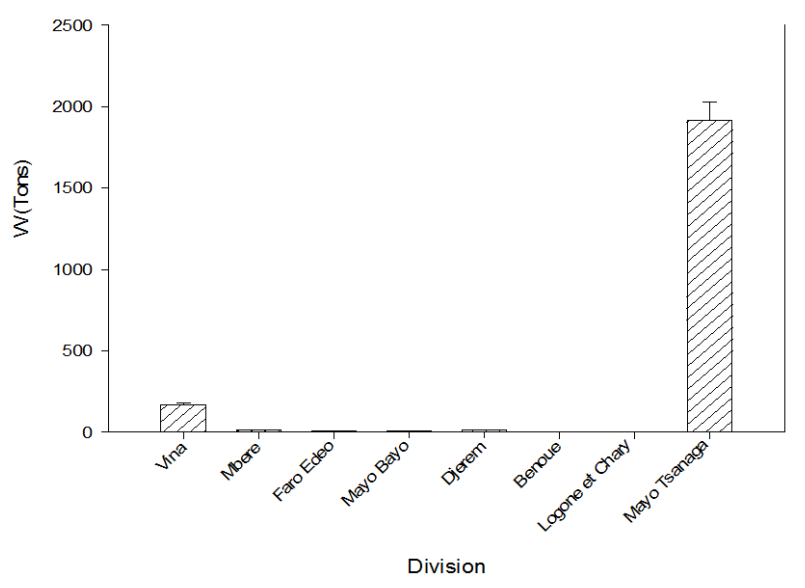

Figure 13. Irish potato peelings dry-bone tons generation.

\section{Conclusions}

The general objective of this work was to quantify, in terms of types, the waste generated in the northern part of Cameroon and to evaluate their associated energy potential.

Amongst the investigated food crops, there is a significant quantity of waste generated in the northern part of Cameroon of about 555002.27 dry-bone tons per annum corresponding to a $41 \%$ of the national generated waste from the same crops. Waste generated by this food crops is classify into three groups: house-hold wastes, agricultural residues and industrial wastes.

The North region has the highest production of waste with a percentage of $42.93 \%$ followed by the Far-North region with a percentage of $42.44 \%$. The Adamawa region has the smallest proportion of $11.23 \%$. The cotton hulls represent $3.41 \%$.

The evaluated potential energy of wastes generated in the northern part of Cameroon is about $11.5 \mathrm{TJ}$ against $27.9 \mathrm{TJ}$ for the national and for the same food crops. These values are underestimated, give that about $10 \%$ of food crops produced in the northern part were not investigated in the present study. The conversion of these wastes into energy will provide a major contribution to the Cameroon energy deficit.

To complete this work, it will be necessary to identify the collected area of house hold wastes and to propose valorization technics adapted to developing countries such as Cameroon.

\section{Acknowledgment}

The authors thank the Ministry of Higher Education of Cameroon for its financial support through the Special Fund Account for the modernization of research in state Universities. They also thank the Geomatic Laboratory of the University of Ngaoundere for the location map building of the study area, and the Agence Universitaire de la Francophonie 
(AUF) for the support under the grant "Soutien aux Equipes de Recherche" (BACGL-2014-53).

\section{References}

[1] Seifried D. and Witzel W., 2007. Renewable Energy -The Facts, Energieagentur Regio Freiburg, 221 p.

[2] Aldo Vieira da Rosa, 2005. Fundamentals of renewable energy processes, Elsevier academic press, 446-610.

[3] Kaltschmitt M. and Wolfgang Streicher A. W., 2007. Renewable energy: Technology, Economics and Environment; Springer-Verlag Berlin Heidelberg, 535 p.

[4] Debra Miller A. 2011. Energy production and alternative energy, Library of congress cataloging-in-publication data, $10-43$.

[5] Vertes A.A., Qureshi Nasib, Blaschek Hans .P, Hideaki Yukawa, 2010. Biomass to Biofuels: Strategies for Global Industries, Wiley, $547 \mathrm{p}$.

[6] Chaney J., 2010. Combustion Characteristics of Biomass Briquettes, Thesis submitted to The University of Nottingham, 225 p.

[7] Ningham and Singh, 2011, Production of liquid biofuels from renewable resources, Progress in Energy and Combustion Science, 37, 52-68.

[8] Sarkar N., Ghosh S.K., Bannerjee S., and Aikat K., 2012. Bioethanol from agricultural wastes. An overview. Renewable energy, 37, 19-27.

[9] Ackom E.K., Alemagi D., Ackom Nana B., Minang P.A. and Tchoundjeu Z., 2013 Modern bioenergy from agricultural and forestry residues in Cameroon: Potential, challenges and the way forward, Energy policy, 101-113.

[10] Agri-Stat, 2012. Annuaire des Statistiques du Secteur Agricole Campagnes 2009 et 2010, №17, Direction des Enquêtes et des Statistiques Agricoles, 123 p.

[11] Devendra C. 1980, Non-conventional feed resources in Asia and Far East. Bangkok: FAO-APHCA, FAO Far East Regional Office, $104 \mathrm{p}$.

[12] FAO, 2002. Index des noms de plantes et des cultures de remplacement, améliorer la nutrition grâce aux jardins potagers. Module de formation à l'intention des agents de terrain en Afrique, Service des programmes nutritionnels, Division de l'alimentation et de la nutrition. Annexe 1, 277-280.

[13] Délégation régionale de l'Extrême-Nord, 2015. Données sur les principales réalisations Agricole de la région du Nord, MINADER, 33-41.

[14] Délégation régionale de l'Adamawa, 2015. Données sur les principales réalisations Agricoles de la région de l'Adamaoua, MINADER, 1-11.

[15] Délégation régionale du Nord, 2015. Données sur les principales réalisations Agricoles de la région du Nord, MINADER, 61-62.

[16] ASTM standards, 2006, Standard Test Method Moisture Analysis of Particulate Wood Fuels, E 1871-82.
[17] ASTM standards, 2006, Standard Test Method for Volatile Matter in the Analysis of Particulate Wood Fuels, E 872 - 82.

[18] ASTM standards, 2007, Standard Test Method for Ash in Biomass, E 1755-01.

[19] García R., Pizarro C., Lavín A.V., Bueno J.L., 2012. Characterization of Spanish biomass wastes for energy use, Bioresource Technol, DOI:10.1016/j.biortech.2011.10.004; 103, $249-258$.

[20] Institut National de la statistique Cameroun, 2015. Ministère de l'économie, de la planification et de l'aménagement du territoire, Annuaire de statistique 2015.

[21] IRAD, 2014. Cinquante ans de recherche agricole au Cameroun: Principaux résultats et acquis, Ministère de la recherche sciences et innovation, $93 \mathrm{p}$.

[22] Vargas-Moreno J.M, Callejón-Ferre A.J, Pérez-Alonso J. and Velázquez-Martí B, 2012. A review of the mathematical models for predicting the heating value of biomass Materials, Renewable and Sustainable Energy Reviews, 3065-3083.

[23] Lee Sunggyu and Shah Y. T. 2013, Biofuels and Bioenergy Processes and Technologies, CRC Press Taylor \& Francis Group, 292 p.

[24] Debdoubi A., El amarti A. and Colacio E., 2004. Production of fuel briquettes from esparto partially pyrolyzed, Energy Conversion and Management, 1877-1884.

[25] ADEME, 2008. Référentiel combustible bois énergie : les connexes des industries du bois définition et exigences. Convention 0601c0005, République françaises, $62 \mathrm{p}$.

[26] Bianca G. de Oliveira Maia, Ozair Souza, Cintia Marangoni, Dachamir Hotza, Antonio Pedro N. De Oliveira, Noeli Sellin, 2014. Production and Characterization of Fuel Briquettes from Banana Leaves Waste, Chemical Engineering Transactions, VOL. 37 P 439-444.

[27] Onwuka C.F.I, Adetiloye P.O. b, Afolami C.A., 1997. Use of household wastes and crop residues in small ruminant feeding in Nigeria, Small Ruminant Research, 24, 233-237.

[28] Adeyi and Oladayo, 2010. Proximate composition of some agricultural wastes in Nigeria and their potential use in activated carbon production. J. Appl. Sci. Environ. Manage, 14 (1), 55-58.

[29] Sami M., Annamalai K. and Wooldridge M., 2000. Co-firing of coal and biomass fuel blends; Progress in Energy and Combustion Science; 171-214.

[30] Jigisha Parikha, S.A. Channiwalab, G.K. Ghosal, 2005. A correlation for calculating HHV from proximate analysis of solid fuels, Fuel 84, 487-494.

[31] Murali S., Shrivastavo R. and Saxena M., 2007. Quantification of agricultural residues for energy generation -A case Study, Journal of IPHE India, 27-31.

[32] Jenkins BM, Ebeling JM, 1985. Correlation of physical and chemical properties of terrestrial biomass with conversion: symposium energy from biomass and waste IX IGT, $371 \mathrm{p}$.

[33] Bhajan Dass and Pushpa Jha, 2015 Biomass Characterization For Various Thermochemical Applications, International Journal of Current Engineering And Scientific Research, 59-63.

[34] Demirbas A., 1997. Calculation of higher heating values of biomass fuels, Fuel 76 (5), 431 p. 
[35] Slavko N., Djuric, Saša D. Brankov, Tijana R. Kosanic, Mirjana B.C., and Branka B.N.S., 2014. The composition of gaseous products from corn stalk pyrolysis process, Thermal Science, $18,533-542$.

[36] Oladeji J.T, 2012. Comparative Study of Briquetting of Few Selected Agro-Residues Commonly Found in Nigeria "The Pacific Journal of Science and Technology, 13, 80-86.

[37] Jekayinfa S. and O. Omisakin., 2005. The Energy Potentials of some Agricultural Wastes as Local Fuel Materials in Nigeria; Agricultural Engineering International: The CIGR Ejournal., Vol.VII. Manuscript EE 05 003, 10 p.

[38] Olufunke O. Ezekiel1, Ogugua C. Aworh, Hans P. Blaschek and Thaddeus C. Ezeji, 2010. Protein enrichment of cassava peel by submerged fermentation with Trichoderma viride (ATCC 36316), African Journal of Biotechnology Vol. 9 (2), 187-194.

[39] Jianfeng Shen, Shuguang Zhu, Xinzhi Liu, Houlei Zhang and Junjie Tan, 2009. The prediction of elemental composition of biomass based on proximate analysis, Energy Conversion and Management, 984-987.

[40] Jenkins B.M., Baxter L.L., Miles Jr. T.R. and Miles T.R., 1998. Combustion properties of biomass, Fuel Processing Technology, 17-46.

[41] Lacour J.R., Bayard E. and Gourdon E.R., 2011. Evaluation du potentiel de valorisation par digestion anaérobie des gisements de déchets organiques d'origine agricole et assimilés en Haïti, Déchets - revue francophone d'écologie industrielle - $n^{\circ} 60$, 32-36.
[42] Onesias Gup-pens and Gerin P., 2009. Valorisation de la biomasse-énergie en Haiti : Analyse de la situation et perspectives d'amélioration, Mémoire de Master, Université Quisqueya, $50 \mathrm{p}$.

[43] Freitas Komlanvi. I, 1976. Etude des produits et sous-produits agro-industriels du Togo possibilités de leurs utilisations en élevage, Thèse, université de Dakar-Togo, 131 p.

[44] Koopmans A. and Koppejan J., 1998. Agricultural And Forest Residues Generation, Utilization And Availability Wood Energy Conservation Specialists Regional Wood Energy Development Programme in Asia, $23 \mathrm{p}$.

[45] Kimutai S.K., Muumbo A.M., SIAGI Z.O. and Kiprop A.K., 2014. A study on agricultural residues as a substitute to fire wood in Kenya: a review on major crops. Journal of Energy Technologies and Policy, 4(9), 45-51.

[46] OECD/IEA Suitainable production of second generation biofuel, potential and perspective in major economies and developing countries information paper accessed $7^{\text {th }}$ (http:iea.org/papers/2010/second), $12 \mathrm{p}$.

[47] Ryan P. and Openshaw K. (1991), Assessment of Biomass Energy Resources: A discussion on its needs and methodology, The World Bank Industry and Energy Department, 77 p.

[48] UNEP, 2010. Project on converting waste agricultural biomass to an energy / material resource. Report II, Waste biomass quantification and characterization. National Cleaner Production Center, Sri Lanka, 121 p. 